\title{
Online Bussiness Interest Factor Analysis for Students
}

\author{
Melinda Siregar ${ }^{1, a^{*}}$, Siti Aisyah Nasution ${ }^{2}$ \\ ${ }^{1}$ Department of Management, Universitas Prima Indonesia, Medan, Indonesia \\ ${ }^{2}$ Department of Accounting, Universitas Prima Indonesia, Medan, Indonesia \\ a melindasiregar@unprimdn.ac.id \\ *Corresponding Author: melindasiregar@unprimdn.ac.id [ Phone : +6281396866660 ]
}

\section{Abstract}

This study aims to see how the factors that arise on the interests that affect students in doing business online. Online business has several factors that influence the development of student interest. Some students think that they will become unemployed after college, or that they will find it difficult to get a job later, and so on. Based on the results of the research conducted, it was found that there were educational and environmental factors that were very influential in the progress of student interest in doing online business. The sample used in this study were 20 students from the entire student population. The method used in this research is survey method and quantitative analysis method. This study uses a questionnaire instrument in data collection. The data obtained in the education factor is the $t$-count value of the education variable $>$ from the $t$-table, namely $(3.251>2.086)$ and a significant value $(0.000<0.05)$. And for environmental factors, the $t$-count value for environmental variables is <than the $t$-table value, namely $(1.552<2,086)$ and a significant value $(0.255>0.05)$. From the test results, the value of the $\mathrm{F}$ table is 2.71 at the level of alpha $=0.05$ degrees of freedom of the numerator 3 and the denominator is 16 . Obtained F count is $4.513>$ than the F table is 3.10 . This comparison shows that the influence of education and environmental factors simultaneously has an impact on student interest in doing business online.

Keywords: online bussines; interest; factor analysis;

\section{Introduction}

Indonesia is a developing country that has a fairly high population growth rate. This makes the level of competition between individuals to survive increases as well. High population growth among Indonesians when it is not followed by the availability of adequate employment opportunities will create a very epic problem, namely unemployment. The next stage is the emergence of a new problem, namely poverty. Unemployment in Indonesia is very worrying, even reaching millions of people in the 2018-2019 era. From 2014, 2015 to February 2016, it increased from 6.4 million to 7.45 million people in just 2 years. This condition is of course very concerning. One of the ways to overcome the problems mentioned above is by doing business or doing business using the internet. The rapid development of the internet in Indonesia provides an opportunity to overcome unemployment by organizing online businesses. In Indonesia, internet usage has grown from year to year, starting from only 16 million people in 2005 to reaching 88.1 million in 2014 . Sumatra itself, namely North Sumatra, has the largest number of internet users, namely 3.6 million users. with a $25 \%$ growth in new internet users. Students as among the younger generation have the opportunity to become an online businessman. Students are generally able to master IT or the Internet so that they respond more quickly to the times and developments in the technological era in the digital world. To be able to become a reliable online businessman requires creativity, innovation, including strong interest. Interest is a mental set consisting of a mixture of feelings, hopes, convictions, tendencies that direct the individual to a particular choice. Interest influences one's learning process and outcomes because if someone is studying something with great interest, it can be expected that the results will be better. In addition, someone's interest can be expressed through statements that show someone is more interested in another object (Suharti \& Sirine, 2011). Therefore, interest is the main rule in responding to something, including entrepreneurial interest among students. Interest in entrepreneurship among students can be influenced by various factors, including: (1) Education, if education is adequate, a person will be ready to become an entrepreneur. and lead his men; and (2) Family and community environment, the more conducive the family environment and the community around it, the more it will encourage someone to become an entrepreneur. 
Based on the identification of various problems as previously described, this study aims to determine how the factors of education, environment, and availability of internet services influence students' interest in doing online business (e-business). Currently, the trend is online business, students are expected to be able to get their own opportunities and income in terms of self-development in facing situations like today.

\section{Research Method}

\subsection{Research Location, Materials and Tools}

\section{Research Location}

This study was conducted at Prima Indonesia University, Management Study Program, even semester, from August to October 2020.

\subsection{Population and Sample}

The population in this study were all students of the Even semester Management Study Program, Prima Indonesia University. The sample used was 20 Management Study Program students from even Semester 2020.

\subsection{Research Design, Work Procedure, and Observation}

T Specifically for this study, the author intends to analyze the relationship between education, environment and the availability of internet services with students' interest in doing business online (online shop). The research sample was 20 students of the management study program at UNPRI, especially the fourth semester students. Sampling using one of the types of non probability sampling, namely accidental sampling. The research data collection technique used a questionnaire. Meanwhile, the data analysis technique used in this study was quantitative data analysis, namely using multiple linear regression. The research implementation procedure was to analyze the data obtained from the questionnaire on student sample respondents. The method used in this research is quantitative analysis method. The type of research in this thesis is an explanatory research that is associative, namely research that aims to determine the relationship between two or more variables.

\section{Results and Discussion}

\subsection{Results}

Result of The Test Trials on 2 Factors, namely, education, environment, and General(no factor) are follows :

Table 1. Partial T Test Results

\begin{tabular}{|c|c|c|c|c|c|c|}
\hline \multirow[b]{2}{*}{ Model } & \multicolumn{2}{|c|}{ Unstandardized Coefficients } & \multicolumn{2}{|c|}{ Standardized Coefficients } & \multirow[b]{2}{*}{$\mathrm{t}$} & \multirow[b]{2}{*}{ Sig. } \\
\hline & $\mathrm{B}$ & Std error & Beta & & & \\
\hline Constant & 1.108 & 1.98 & & & 0.56 & 0.577 \\
\hline Education & 0.369 & 0.99 & & 0.348 & 3.251 & 0 \\
\hline Environment & 0.139 & 0.124 & & 0.104 & 1.552 & 0.255 \\
\hline General (no factor) & 0.341 & 0.072 & & 0.432 & 4.345 & 0 \\
\hline
\end{tabular}

Table 2. The Result of Each Factor

\begin{tabular}{|c|c|c|c|}
\hline No. & Factor & t- count Result & $\mathrm{t}$-table result \\
\hline 1 & Education & 3.251 & 2.086 \\
\hline 2 & Environtment & 1.552 & 2.086 \\
\hline 3 & General (not a factor)such as public service & 4.345 & 2.086 \\
\hline
\end{tabular}

\section{Information :}

1. This means that if the value of the education variable increases, the value of interest in doing business online will also increase.

2. This positive value means that if the value of these variables increases, the value of interest in doing business online will increase but has no real effect.

3. If the variable value of public service availability increases, the value of interest in doing business online will increase. 
Table 3. F Test Results

\begin{tabular}{lccccc}
\hline \multicolumn{1}{c}{ Model } & Sum of Squares & df & Mean Square & F & Sig \\
\hline Regression & 375.857 & 3 & 125.29 & 45.132 & 0 \\
\hline Residual & 250.498 & 16 & 15.66 & & \\
\hline Total & 650.455 & 19 & & & \\
\hline
\end{tabular}

Information:

The value of Ftable in Table 2 is 2.71 (at the level of $a=0.05$; degrees of freedom of the numerator $=k-1=4-1$ $=3$; and degrees of freedom of the denominator $=n-k=20-4=16$ ). Thus, based on the values in table 2 , it can be seen that the Fcount value is $45,132>$ Ftable value is 3.10 with a significance level of $0.000<a$ of 0.05 . The comparison of the two shows that the effect of environmental education and the availability of public services simultaneously or simultaneously on students' interest in doing business online is significant.

\subsection{Discussion}

The results showed that simultaneously (together) the variables of education, environment and public service availability had a positive and significant effect on students' interest in doing business online. Partially, the education factor is positive and significant, and the availability of public services has a positive and significant effect on the interest in doing business online. Meanwhile, environmental variables have a positive but insignificant effect. The results of this study will be discussed by making comparisons with previous studies, as follows. First, the influence of educational factors on the interest in doing business online. The results showed that the educational factor had a positive and significant effect on the interest in doing business online. This means that if the educational factor increases, student interest in doing business online will also increase. All these studies lead to the conclusion that education, training and the like have an influence on the interest in doing business online. Second, the influence of environmental factors on the interest in doing business online.

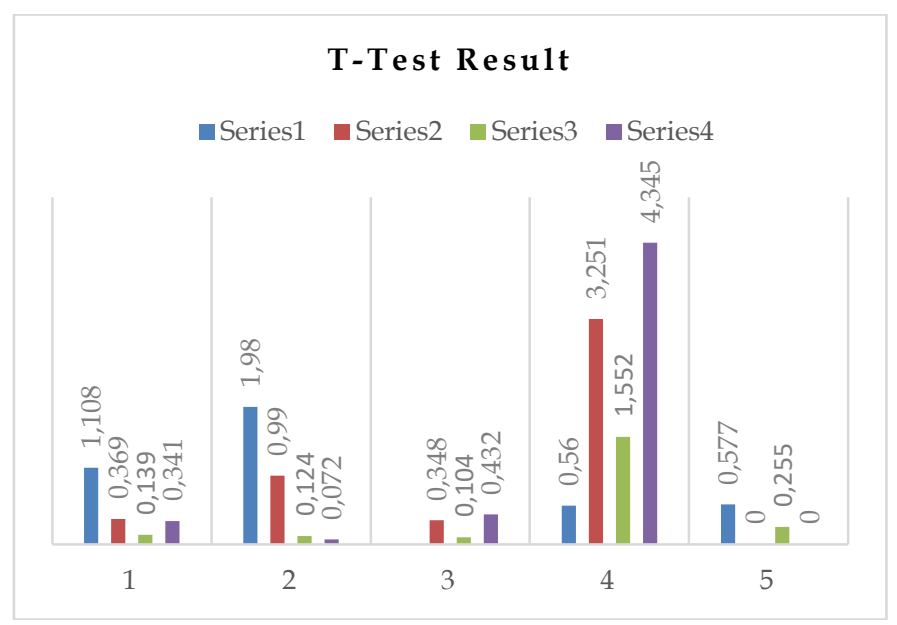

Figure 1. T-Test Result Chart Bar

information :

1. series 1 is the value of Constant

2. series 2 is the value of Education

3. series 3 is the value from Environment

4. series 4 is General/public service (not factor)

The second result of This study shows that environmental factors have a positive but insignificant effect on the interest in doing business online. This results means that if environmental factors increase, students' interest in doing business online will also increase, but the relationship is not real or meaningless. 


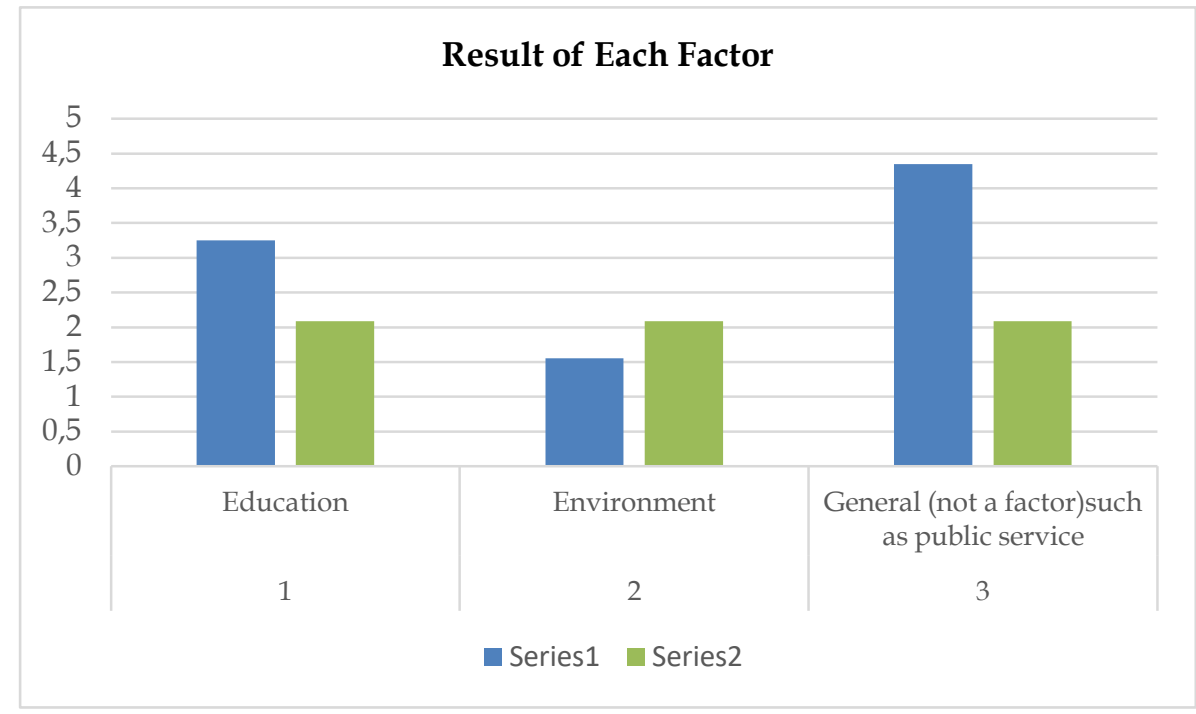

Figure 2. Result of Each Factors

Therefore, the results of this study are different from the results of studies that have been reviewed in the previous literature review. Third, the influence of the availability of public services on the interest in doing business online. The data have proven that the factor of internet service availability has a positive and significant effect. These results illustrate that if the factor of internet service availability increases, students' interest in doing business online will also increase. Thus, the results of this study are consistent with research conducted by previous studies which also informs that public services affect the world of work and business.

\section{Conclusion}

From the research results, the conclusions are obtained, namely:

1. on the educational factor, the $t$ count is greater than $t$ table, namely $3.251>2.086$, meaning that if the value of the education variable increases, the value of interest in doing business online also increases

2. on environmental factors, obtained $t$ count is smaller than $t$ table, $1.552<2.086$ means that environmental variables have a positive but insignificant effect on interest in doing business online, the value is positive, meaning that if these variables increase, the value of interest in doing business online will increase but has no significant effect .

3. public services, obtained $t$ count greater than $t$ table, $4.345>2.086$ means that public services have a positive and significant effect on the interest in doing business online, thus if the value of the variable public services increases, the interest in doing business online will also increase.

\section{References}

Adhitama, P. P. (2014). Faktor - faktor yang mempengaruhi minat berwirausaha : Studi kasus mahasiswa Fakultas Ekonomika dan Bisnis UNDIP. Universitas Diponegoro Semarang.

Aionok, K. S., Isoraite, M., \& Hussey. B. L. (2016). The Internet Enterpreneurship : Opportunities and Problems. Enterpreneurship and Sustainability Issues . 3(4), 329-249.

Bygrave, W., \& Zacharakis, A. (2011). Entrepreneurship. Babson Park: John Willy \& Sons. Chaffey, D., EllisChadwick, F., Mayer, R., \& Johnston, K. (2006). nternet marketing: Strategy, implementation and practice. London: Pearson Education Limited.

Cuervo, Á., Ribeiro, D., \& Roig, S. (2006). Entrepreneurship: Concept, theory and perspective. Harlow England: Springer . Dubini, P. (1989). The influence of motivations and environment on business start-ups: Some hints for public policies. Journal of Business Venturing , 4 (1), 11-26

Franco, M., Santos, M. d., Ramalho, I., \& Nunes, C. (2014). An exploratory study of entrepreneurial marketing in SMEs: The role of the founder-entrepreneur. Journal of Small Business and Enterprise Development , 21 (2), 265-283.

Koranti, K. (2013). Analisis pengaruh faktor eksternal dan internal terhadap minat berwirausaha. Seminar Ilmiah Nasional Psikologi, Ekonomi, Sastra, Arsitektur, dan Teknik Sipil (PESAT). Jakarta: Universitas Gunadarma 
Laudon, K. C., \& Laudon, J. P. (2014). Management information systems: Managing the digital firm. Edinburgh Gate: Pearson Education Limited.

Lestari, R. B., \& Wijaya, T. (2012). Pengaruh pendidikan kewirausahaan terhadap minat berwirausaha mahasiswa di STIE MDP, STMIK MDP, dan STIE MUSI. Jurnal Ilmiah STIE MDP , 1 (2), 112-119

.Suryosubroto, B., (2002), Teaching and Learning in Schools, Rineka Cipta Publisher, Jakarta.

Lecturer Team, (2008), Anatomy of Human Physiology, Faculty of Mathematics and Natural Sciences, Medan State University.

Usman, H, (2006), Introduction to Statistics, Tarsito Publisher, Bandung.

Usman, U.M, (2006), Efforts to Optimize Teaching and Learning Activities, Publisher of PT Remaja Rosdakarya, Bandung.

Zubaidah, (1999), Improving Motivation for SLTP Laboraturium students' learning at Negerig State University Through Concept Maps, PTK Articles, Malang. 